Alma Mater Studiorum - Università di Bologna DEPARTMENT OF ECONOMICS

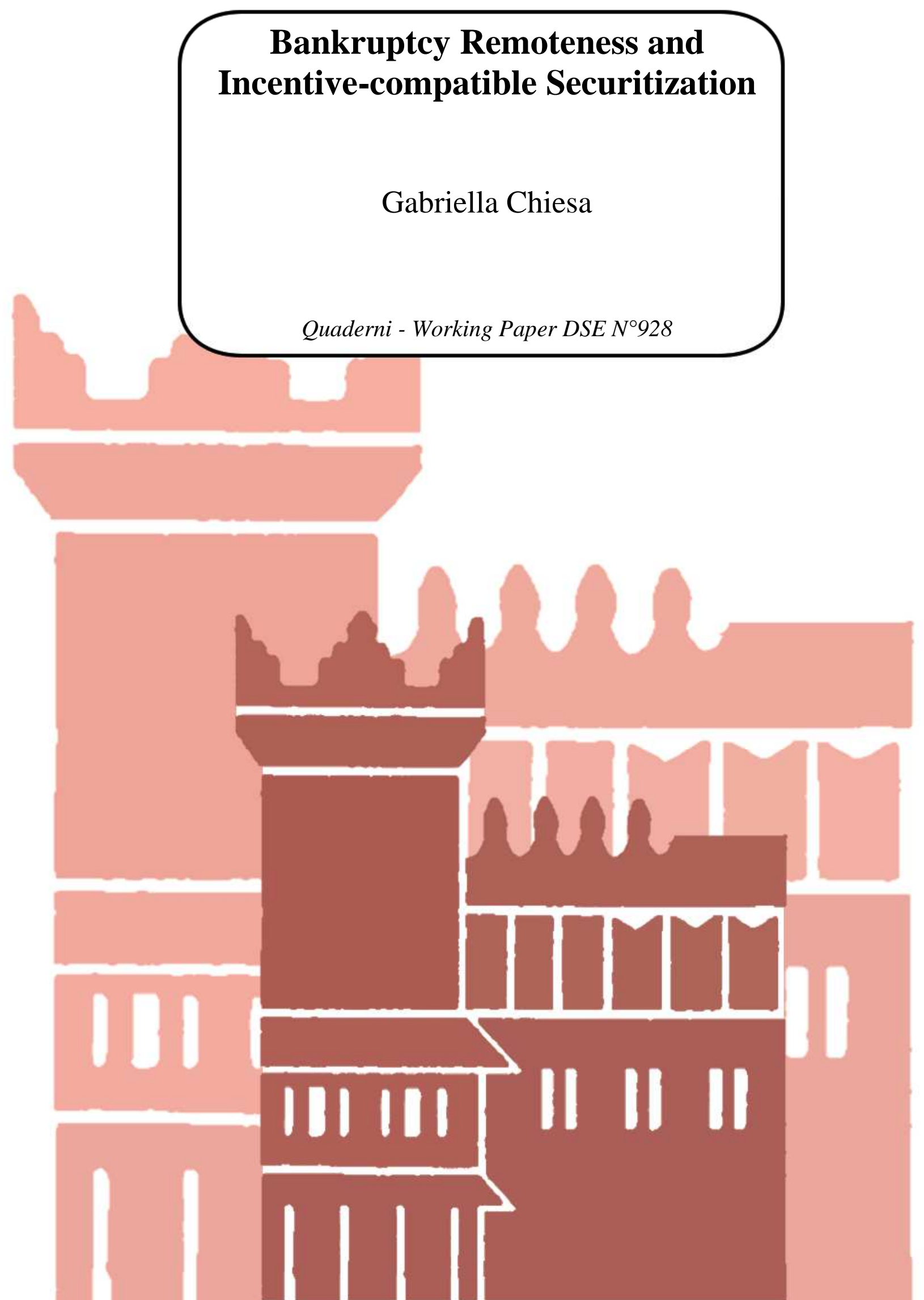




\title{
Bankruptcy Remoteness and Incentive-compatible Securitization
}

\author{
Gabriella Chiesa \\ Department of Economics \\ University of Bologna
}

\begin{abstract}
Securitization performs two functions. One refers to the risk allocation between the bank and outside investors; the other consists of creating transferable/liquid securities. A key ingredient of liquidity/claimtransferability is bankruptcy remoteness - the insolvency of the sponsor (the loan originator) has no impact on the securities. We explore the implications of bankruptcy remoteness on risk allocation and regulatory/policy issues. Under traditional banking, when debt/deposits coexist with securitization, bankruptcy remoteness amounts to: i) a seniority structure where debt/deposits (the claim that insist on the bank as a whole) have the lowest priority; ii) the bank finds it optimal to grant securities maximum protection - securitization without risk transfer. This constrains incentive-compatible lending below the social optimum, whenever at an optimal allocation not all risk bears on the bank. Policies that implement the social optimum are derived.
\end{abstract}

JEL classification: G21; G28; K22; D86

Keywords: Securitization; Bankruptcy remoteness; Risk transfer 


\section{Introduction}

Securitization can be viewed performing two functions. One refers to risk allocation: the transfer of risks from the banking sector to outside investors - deep-pocketed investors who are better able to absorb losses would share in the risk. The other function consists of creating transferable/liquid securities (Gorton and Metrick, 2012; Shin, 2010). A key ingredient of liquidity/claimtransferability is bankruptcy remoteness: the insolvency of the sponsor (the bank that has originated the loans) has no impact on the securities. Indeed, securitization involves the transfer of ownership of assets (e.g. loans) to a separate legal entity (a special purpose vehicle, or SPV) which then sells claims on the assets to outside investors in exchange for liquid funds. The transfer of ownership of the underlying assets to a separate legal entity allows the bank (loans originator) to establish the bankruptcy remoteness of the SPV and the transferred assets (Ayotte and Gaon, 2011). ${ }^{1}$

Bankruptcy remoteness results from Court decisions and regulatory rules that allowed securitization and REPO special treatment under the bankruptcy code. "Regulatory changes were an endogenous response to the demand for efficient bankruptcy-free collateral in large financial transactions" (Gorton and Metrick, 2010).

The evidence on securitized loans' defaults is that the bulk of the losses (loan/mortgages defaults) were borne by the banking sector (Greenlaw et al., 2008). Acharya et al. (2013) document that commercial banks provided insurance to investors. Commercial banks have engaged in explicit legal commitments to repurchase asset backed securities. For the majority of SPVs, the credit guarantees were strong enough to cover all possible losses of outside investors.

The evidence thus suggests that investors (security holders) had recourse to the bank's balance sheet, via contractual credit guarantees, which means that risk remained on banks, and at the same time the investors were/are protected from bank's illiquidity/insolvency, via bankruptcy remoteness.

We explore the implications of securities' bankruptcy remoteness on risk allocation and the regulatory/policy issues it gives rise. Assuming the bank securitizing the loans cannot steal money outright, will depositors' interest

\footnotetext{
${ }^{1}$ Ayotte and Gaon (2011) provide evidence that the creditor protection provided by bankruptcy remoteness is indeed valuable and priced in financial markets.
} 
be diluted? What the implications for regulation?

We address these questions within a model where loan return distribution is state contingent and bank costly monitoring is valuable in every state. $^{2}$ Value maximization would require that the monitoring agent (the bank) retains the risk it can control via monitoring and is insulated from the exogenous risk (the realization of state of nature).

We show that under traditional banking, when debt/deposits coexist with securitization, bankruptcy remoteness amounts to: i) a seniority structure where debt/deposit (the claims that insist on the bank as a whole) have the lowest priority; ii) the bank finds it optimal to grant securities maximum protection: securitization without risk transfer.

This implies that if at an optimal allocation all risk bears on the bank, then bankruptcy remoteness does not harm social welfare and does not dilute depositors' interests. By contrast, if at an optimal risk allocation, (exogenous) risk would be transferred to outside investors (security buyers), securities' maximum protection prevents welfare maximization: it dilutes the bank's monitoring incentives and by so doing it dilutes the de-facto junior claims (deposits).

This suggests that under deposit-taking banking, the creation of transferable/liquid securities carries a welfare cost. Measures aimed at aligning incentives succeed to the extent that make the bank (loan originator) to internalize the cost of misallocating risk. We explore two avenues for attaining this goal. One is capital regulation, capital requirements on loans conditioned on the extent of retained risk (albeit, via off-balance sheet commitments). The other is "narrow-securitized banking", attainable with outright restrictions on bank activity, and/or by a capital regulation of banks that imposes the same capital requirement on loans, irrespective of whether loans are securitized or held on the balance sheet. We show that under narrow-securitized banking the optimal allocation attains. Bank profits (and welfare) are maximized by constructing a (well defined) portfolio and placing securities backed by the portfolio. Securities are ranked by seniority, and the

\footnotetext{
${ }^{2}$ The relevance of banks' monitoring role is at the centre of the financial intermediation literature; see Campbell and Kracaw (1980), Diamond (1984), Fama (1985), Hellwig (1991), Bhattacharya and Chiesa (1995), and Holmstrom and Tirole (1997); see also the banking literature review by Bhattacharya and Thakor (1993). There is also ample evidence that bank monitoring improves the quality of the firms financed (Datta, IskandarDatta and Patel, 1999; James, 1987; Lummer and McConnell, 1989).
} 
safe claims that depositors (and more generally, some classes of investors) target are made such by granting them absolute priority.

This paper relates to the literature on security design and securitization. Benveniste and Berger (1987) show that the allocation of risk among bank liability holders is optimized by the appropriate design of multiclass securities. Allen and Carletti (2006) analyze the role of credit derivatives in the allocation of risk across sectors. DeMarzo (2005) has shown how asset pooling and tranching may reduce informational asymmetries. Fender and Mitchell (2009), and Cerasi and Rochet (2013) analyze the role of tranche retention in the provision of screening and monitoring incentives. Several papers claim that either exogenous reserve or capital requirements create the need for securitized bank loans (Pennacchi, 1988; Gorton and Pennacchi, 1995; Carlstrom and Samolyk, 1995). By contrast, our model attempts to rationalize endogenously securitization as a mechanism to insulate the monitoring bank from exogenous risk so as to implement the optimal reward schedule and with it value maximization. Much of the previous literature argues that securitization and more generally risk transfer weakens monitoring incentives (Pennacchi, 1988; Gorton and Pennacchi, 1995; Duffee and Zhou, 2001; Morrison, 2005; Parlour and Plantin, 2008; Parlour and Winton, 2013). In all these works the optimal reward schedule is that defined by standard debt (the return distribution satisfies the conditions in Innes, 1990). Aggregate/systematic risk plays an important role in optimal contract design. In Chiesa (2008) systematic risk implies that the loan-portfolio return distribution fails to satisfy the monotone-likelihood ratio property (MLRP), and this makes debt suboptimal. In our set-up MLRP holds but debt is suboptimal because it offers poor incentives in bad states. An optimal securitization scheme improves incentives by lowering the debt burden in bad states. This requires security holders to bear risk: a value-maximizing securitization scheme provides investors with a well defined limited protection. We take for granted the institution of bankruptcy remoteness. In our simplified model, this is an exogenous constraint the bank cannot remove. In a more general and realistic model, bankruptcy remoteness would be rationalized by the welfare gains it generates by minimizing the information gathering of security buyers and thereby the liquidity/transferability of claims (along the reasonings of Dang-Gorton-Holmstrom, 2012). The key problem we focus on are the bank's incentives to design securitization and primarily credit 
enhancement/protection in an environment where bankruptcy remoteness insulates security holders from bank's illiquidity/insolvency.

The paper is organized as follows. Section 2 presents the model. Section 3 derives the optimal risk allocation, and shows that risk would be shared between the bank and investors. Debt financing (risk retention) is suboptimal: it provides poor monitoring incentives in bad states - "debt overhang" (Section 4). Section 5 shows that debt-suboptimality gives scope for welfare-improving securitization. However, under traditional banking, where deposit/debt financing coexist with securitization, welfare-improving securitization is not incentive compatible. The key is in that bankruptcy remoteness of securities gives them absolute priority. The bank profits by granting securities maximum protection (risk retention). This amounts to diluting junior claims (deposits/debt claims), and this dilution derives exclusively from the dilution of bank's monitoring incentives. Section 6 analyses the role for prudential regulation. Section 7 concludes.

\section{The Model}

There are 3 dates, 1,2,3, and three actors: households (unsophisticated investors), sophisticated investors, and banks. Investors have real resources but lack the monitoring expertise for undertaking real investment projects, either directly or indirectly by financing firms. Banks have the required monitoring expertise. Real investment projects will be ultimately funded by investors, but the financial claims investors target differ. Sophisticated investors have expertise in valuing asset portfolios and are interested in claims whose performance exclusively depends on portfolio performance. They target asset-backed securities (securitized assets), these securities can be traded and/or used as collateral in REPO. Indeed, investors in securitized assets and/or counterparts in REPO need only to know (acquire information on) the asset portfolio backing the securities rather than the bank's assets as a whole and its degree of leverage - the liability side of the bank that has originated the assets.

Unsophisticated investors (households) target safe, information-insensitive securities: debt claims - possibly insured deposits. Households are a cheap source of financing. Provided claims are safe, their required gross return per unit is $z \leq 1$ and the total amount of funds supplied is $\bar{D}$. Sophisticated 
investors' required gross return is 1 .

A bank has the opportunity to finance a portfolio (continuum) of loans whose size $L$ is derived endogenously. Moreover, like sophisticated investors, it has access to a storage technology (safe asset) whose gross return per unit is 1. It funds its asset portfolio out of internal funds (capital) and outside financing.

The bank acts on behalf of its shareholders (insiders), whose equity holdings constitute the bank's endowment of inside capital, $K$.

\subsection{Project Technology and Monitoring}

Lending consists in project financing. A project requires one unit of resources at date 0 and gives a pledgeable return $X \in\{0, R\}$ at the final date 2.

The probability of success of a project, $\operatorname{Pr}(X=R)$, is $\alpha \in\left\{\bar{\alpha}, \alpha_{M}, \underline{\alpha}\right\}$,

$$
\bar{\alpha}>\alpha_{M}>\underline{\alpha} \geq 0 \text {. }
$$

Project success probability depends on whether the project has been monitored by the bank and on the realization of a common risk factor (state of nature). State realization is good, denoted with $g$, with probability $p$ and is bad, $b$, with residual probability $1-p$. Conditional on state realization $g$, the success probability of a monitored project is $\bar{\alpha}$, that of an unmonitored project is $\alpha_{M}$. Conditional on state realization $b$, the success probability of a monitored project is $\alpha_{M}$, that of an unmonitored project is $\underline{\alpha}$. At the interim date, $t=1$, the bank privately observes state realization and chooses loan monitoring. The time line below shows the sequence of events:

$\begin{array}{ccc}\text { Lending } & \begin{array}{c}\text { Bank observes state } \\ \text { realization and chooses } m / \emptyset\end{array} & \begin{array}{c}\text { Realization of } \\ \text { returns }\end{array} \\ \cdot=0 & \cdot & \cdot \\ t=1 & t=2\end{array}$

where: $m \equiv$ monitoring; $\emptyset \equiv$ non-monitoring.

Table 1 shows the distribution of project return conditional on the bank's action and the state realization. 
Table 1

Project return distribution

Bank's action

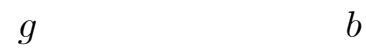

$$
\begin{array}{lll}
m & \operatorname{Pr}(X=R)=\bar{\alpha} & \operatorname{Pr}(X=R)=\alpha_{M} \\
\varnothing & \operatorname{Pr}(X=R)=\alpha_{M} & \operatorname{Pr}(X=R)=\underline{\alpha}
\end{array}
$$

Monitoring has a cost to the bank of $F>0$ per project. This is a nonpecuniary effort cost. $F$ may also be interpreted as the opportunity cost of eschewing insider lending, forgoing the private benefits of collusion with the borrower.

We further specify the model by making the following assumptions:

Assumption A1. Monitoring is value increasing in every state:

$$
\begin{aligned}
& \left(\bar{\alpha}-\alpha_{M}\right) R>F \\
& \left(\alpha_{M}-\underline{\alpha}\right) R>F
\end{aligned}
$$

Assumption A2. A project that is monitored in every state has positive net present value:

$$
\left[p \bar{\alpha}+(1-p) \alpha_{M}\right] R>1+F
$$

Assumption A3. Conditional on the bad state realization, the expected return of a monitored project is lower than the amount of resources invested:

$$
\alpha_{M} R<z+F
$$

This will imply that the amount of debt financing the bank can raise conditional on finding it incentive compatible to monitor is constrained.

Assumption A4. The bank's monitoring choice and the state realization are unobservable. Returns are observable and verifiable.

Contracts can then be made contingent only on return realizations.

Our assumptions imply that: (i) bank monitoring increases loan value and is unobservable to outsiders and costly to the bank; (ii) the bank learns 
private information about loan return distribution after contracts are signed and before it chooses monitoring effort.

Chiesa (1992) shows that when the borrower learns information after contracting and before it chooses its effort, debt financing offers poor incentives in bad states. We show that this carries over to our banking context: debt financing under-rewards monitoring in bad states and this implies that bank outside financing and lending volumes are constrained below the optimal levels. Credit derivatives improve incentives and expand bank's incentive-compatible lending by lowering the burden of bank's debt in bad states. $^{3}$

\subsection{Portfolio Outcomes}

We assume that the bank either monitors the entire portfolio or does not monitor at all. That is, we rule out monitoring of only some loans. This simplifies the exposition with no loss of generality. Indeed, since the monitoring technology has constant return to scale, partial monitoring is never optimal. We also assume, for simplicity, that loan portfolios are perfectly diversified, so that idiosyncratic risk is diversified away. Outcomes are thus centered on the mean, which depends on the state realization and on the bank's monitoring choice.

Let $s$ denote the loan-solvency rate realization. For a diversified portfolio, $s$ can be equal to $\bar{\alpha}, \alpha_{M}$ or $\underline{\alpha}$.

Clearly, certain outcomes signal the bank's action. For example, the outcome $s=\underline{\alpha}$ perfectly reveals that the bank has not monitored. Likewise, $s=\bar{\alpha}$ reveals that the bank has monitored. By contrast, $s=\alpha_{M}$ is nonrevealing; $s=\alpha_{M}$ if either the state realization is good and the bank has not monitored or the state realization is bad and the bank has monitored.

\section{Social Optimum}

\footnotetext{
${ }^{3}$ Aggregate/systematic risk, captured by the realization of the state of nature, plays an important role in optimal contract design. In Chiesa (2008) systematic risk implies that the loan-portfolio return distribution fails to satisfy the monotone-likelihood ratio property (MLRP), and this makes debt suboptimal. In our set-up MLRP holds but debt is suboptimal because it offers poor incentives in the bad state.
} 
Unmonitored projects have negative net present value and monitored projects positive, at an optimal solution the size of monitored lending is maximized. That is, at an optimum, the amount of bank's outside financing is maximized subject to the bank's state-contingent incentive-compatibility constraints (the bank must find it profitable to monitor in all states) and the investor's participation constraint (investors make non-negative profits). The cost of raising financing from households is lower than the sure return obtained by investing in the safe asset (the storage technology). Hence at an optimal solution, the maximum amount $\bar{D}$ is invested in the safe asset and the sure net return $\bar{D}(1-z)$ is passed on to investors.

Let $w_{s}$ be the bank's income per unit of loan/project conditional on the portfolio solvency rate realization $s \in\left\{\bar{\alpha}, \alpha_{M}, \underline{\alpha}\right\}$. Investors' income per unit of loan/project conditional on $s$ is then $s R+\frac{\bar{D}(1-z)}{L}-w_{s}$.

Since a monitored project is positive in net-present value, the socialwelfare maximization problem can be expressed as follows:

$$
\begin{gathered}
\max _{w_{\bar{\alpha}}, w_{\alpha_{M}} \cdot w_{\underline{\alpha}}} L \\
\text { s.t. } \\
w_{\alpha_{M}}-F \geq w_{\underline{\alpha}} \geq 0 \\
w_{\bar{\alpha}}-F \geq w_{\alpha_{M}} \\
{\left[p \left[\left(\bar{\alpha} R-w_{\bar{\alpha}}\right)+(1-p)\left[\left(\alpha_{M} R-w_{\alpha_{M}}\right)\right] L+\bar{D}(1-z)=L-K\right.\right.}
\end{gathered}
$$

Condition ( $3 b)$ is the bank's incentive compatibility constraint in the bad state: in state $b$, the bank's profit conditional on monitoring (the LHS of $(3 b))$ must be at least as great as without monitoring, $w_{\underline{\alpha}}$. Condition $(3 g)$ is the incentive constraint in the good state: in state $g$, the bank's profit conditional on monitoring (the LHS of $(3 g)$ ) must be at least as great as without monitoring. This is $w_{\alpha_{M}}$, because in the good state unmonitored portfolio's solvency rate is $\alpha_{M}$. Condition (4) is the investors' participation constraint, that the amount of finance investors provide, $L-K$, equals their expected income - the left-hand side of (4).

Suppose that

$$
\left(p \bar{\alpha}+(1-p) \alpha_{M}\right) R-(1+F) \geq p F
$$


In this case, outside financing would be effectively unconstrained: if (5) holds, then for any $L$ there exist $w_{\bar{\alpha}}, w_{\alpha_{M}}, w_{\underline{\alpha}}$ such that the bank's incentive constraints hold and investors make non-negative profits (for example, $w_{\underline{\alpha}}=$ $\left.0, w_{\alpha_{M}}=F, w_{\bar{\alpha}}=2 w_{\alpha_{M}}\right)$. We rule out this rather uninteresting case by assuming:

$$
\left[p \bar{\alpha}+(1-p) \alpha_{M}\right] R-(1+F)<p F,
$$

Then, outside financing is constrained and maximizing monitored lending amounts to minimizing the bank's expected income per unit of loan subject to the investor's participation constraint and the bank's monitoring incentive constraints:

$$
\begin{gathered}
\min _{w_{\bar{\alpha}}, w_{\alpha_{M}} \cdot w_{\underline{\alpha}}, L}\left[p w_{\bar{\alpha}}+(1-p) w_{\alpha_{M}}\right] \\
\text { s.t. }(3 b),(3 g),(4)
\end{gathered}
$$

At the optimum, bank's incentive constraints bind, i.e. $w_{\underline{\alpha}}^{*}=0, w_{\alpha_{M}}^{*}=$ $F, w_{\bar{\alpha}}^{*}=2 w_{\alpha_{M}}$, and bank's lending is

$$
\begin{gathered}
L^{*}=\frac{K+\bar{D}(1-z)}{c^{*}}, \\
c^{*} \equiv p F-\left\{\left[p \bar{\alpha}+(1-p) \alpha_{M}\right] R-(1+F)\right\} .
\end{gathered}
$$

Let $w_{b}^{*}$ denote the bank's income per unit of loan conditional on the bad state realization, and $w_{g}^{*}$ that conditional on the good state:

$$
\begin{aligned}
& w_{b}^{*}=w_{\alpha_{M}}^{*} \equiv F, \\
& w_{g}^{*}=w_{\bar{\alpha}}^{*} \equiv 2 F .
\end{aligned}
$$

Let $r_{b}^{*}$ denote the investors' profit per unit of loan conditional on the bad state realization, and $r_{g}^{*}$ that conditional on the good state:

$$
r_{b}^{*}=\alpha_{M} R+\frac{\bar{D}(1-z)}{L^{*}}-w_{\alpha_{M}}^{*}-\left[\frac{L^{*}-K}{L^{*}}\right],
$$

that is:

$$
r_{b}^{*}=-p\left[\left(\bar{\alpha}-\alpha_{M}\right) R-F\right],
$$


and

$$
r_{g}^{*}=\bar{\alpha} R+\frac{\bar{D}(1-z)}{L^{*}}-w_{\bar{\alpha}}^{*}-\left[\frac{L^{*}-K}{L^{*}}\right],
$$

i.e.

$$
r_{g}^{*}=(1-p)\left[\left(\bar{\alpha}-\alpha_{M}\right) R-F\right] .
$$

Notice that $r_{g}^{*}>0>r_{b}^{*}($ by $(\mathrm{A} 1))$.

We have:

Proposition 1 At an optimal allocation, risk is shared between the bank and the investors. The bank's income per unit of loan conditional on state realization is:

$$
w_{g}^{*}=2 F, w_{b}^{*}=F .
$$

Investors' profit per unit of loan conditional on state realization is

$$
r_{g}^{*}=(1-p)\left[\left(\bar{\alpha}-\alpha_{M}\right) R-F\right] ; r_{b}^{*}=-r_{g}^{*}\left(\frac{p}{1-p}\right) .
$$

The return to households is $z$ in every state. Lending volume is

$$
L^{*}=\frac{K+\bar{D}(1-z)}{c^{*}}
$$

The proof is very simple: maximization of $L$ requires maximizing outside financing and therefore, because of the investors' participation constraint, the income that the bank can pledge to investors. This amounts to minimizing the loan portfolio return accruing to the bank, conditional on monitoring being incentive compatible in every state. This means that the state contingent incentive constraints bind: $w_{\underline{\alpha}}^{*}=0, w_{\alpha_{M}}^{*}=F, w_{\bar{\alpha}}^{*}=2 w_{\alpha_{M}}$. Substituting into the investors' participation constraint immediately gives Proposition 1.

At an optimal allocation, investors bear risk: investors make a loss in the bad state and get compensated in the good state. The loss they make in the bad state softens bank's incentive constraint in that state and this allows for the volume of incentive-compatible lending to expand. ${ }^{4}$

\footnotetext{
${ }^{4}$ This fits the empirical evidence that risk management allows banks to have greater leverage and make more loans (Cebenoyan and Strahan, 2004).
} 
For future reference, the bank's expected profit with the optimal risk allocation is:

$$
\begin{gathered}
\pi^{*}=\left[p\left(w_{g}^{*}-F\right)+(1-p)\left(w_{b}^{*}-F\right)\right] L^{*}-K \\
=p F L^{*}-K \equiv \\
{\left[\left(p \bar{\alpha}+(1-p) \alpha_{M}\right) R-(1+F)\right] L^{*}+\bar{D}(1-z) .}
\end{gathered}
$$

\section{Debt Financing}

Suppose the bank raises financing from households, then it issues deposits, or more generally debt claims. Assume the debt is safe, then it promises to pay $z$ for unit of resources raised, and since $z \leq 1$, it will maximize profits by raising $\bar{D}$, and invest idle resources $\max (K+\bar{D}-L, 0)$ in the safe asset (the storage technology that gives a gross return of 1 per unit stored).

Assume that available resources, $K+\bar{D}$ do not constrain lending:

$$
K+\bar{D}>L
$$

then bank's revenue will be the sum of the revenue it gets from safe asset holdings, i.e. $K+\bar{D}-L$, and the loan portfolio's revenue which depends on the state realization and the bank's monitoring choice.

Conditional upon the bad state realization, loan portfolio revenue is $\alpha_{M} L R$ if the bank monitors, and $\underline{\alpha} L R$ if it does not. In the bad state, the bank will find it optimal to monitor if:

$\max \left[\alpha_{M} L R+(K+\bar{D}-L)-z \bar{D}, 0\right]-F L \geq \max [\underline{\alpha} L R+(K+\bar{D}-L)-z \bar{D}, 0]$

Clearly, conditionally upon monitoring, the bank must be solvent; for otherwise it would not monitor. The incentive constraint reduces to:

$\alpha_{M} L R+\bar{D}(1-z)-(L-K)-F L \geq \max \{\underline{\alpha} L R+\bar{D}(1-z)-(L-K), 0\}$

If conditionally on non-monitoring the bank is solvent, i.e. if $\underline{\alpha} L R+\bar{D}(1-$ $z) \geq(L-K)$, then the incentive constraint becomes:

$$
R\left(\alpha_{M}-\underline{\alpha}\right) \geq F
$$

which always holds by (A1). This merely says that if it is financially unconstrained the bank would always monitor. Thus, $L$ can be raised at least up to 
the point where the bank is financially constrained, i.e. where it is insolvent when the loan portfolio solvency rate is $\underline{\alpha}$. When $\underline{\alpha} L R+\bar{D}(1-z)<(L-K)$, the incentive constraint is:

$$
\alpha_{M} L R+\bar{D}(1-z)-(L-K) \geq F L
$$

which holds if and only if:

$$
L \leq \frac{K+\bar{D}(1-z)}{1+F-\alpha_{M} R}
$$

Define $c^{D}$ :

$$
c^{D} \equiv 1+F-\alpha_{M} R
$$

This is strictly positive (by (A3)). Moreover, Assumption A3, i.e. $\alpha_{M} R<$ $z+F$, ensures that there exists $\bar{D}$ sufficiently large that satisfies condition (6); i.e., under debt financing, lending is constrained by incentive compatibility and not by the resource constraint.

Lemma 1 If the bank is financed with debt, its incentive-based lending capacity in the bad state is

$$
L_{b}^{D}=\frac{K+\bar{D}(1-z)}{c^{D}} .
$$

By contrast, the incentive-compatibility constraint never binds in the good state. To see why consider the incentive constraint in the good state:

$$
\bar{\alpha} L R+\bar{D}(1-z)-(L-K)-F L \geq \operatorname{Max}\left[\alpha_{M} L R+\bar{D}(1-z)-(L-K), 0\right]
$$

The left-hand side of (7) is the bank's expected profit conditional on monitoring; the right-hand side, on not monitoring. By the same reasoning as above, the incentive constraint in the good state reduces to:

$$
\bar{\alpha} R L+\bar{D}(1-z)-(L-K)-F L \geq 0
$$

which holds for any $L$, because $\bar{\alpha} R>1+F$ (by (A2)-(A3)).

Lemma 2 If the bank is financed with debt, its incentive-based lending capacity in the good state is unlimited:

$$
L_{g}^{D}=\infty .
$$


Clearly, with debt financing the bank's state-contingent incentive-based capacity fails to be equalized across states. The maximum lending volume the bank can undertake such that lending will be monitored in every state is

$$
L^{D}=\min \left\{L_{b}^{D}, L_{g}^{D}\right\} \equiv L_{b}^{D},
$$

and the bank's income per unit of loan conditional on state realization is:

$$
\begin{gathered}
w_{b}^{D}=F, \quad \text { in the bad state, } \\
w_{g}^{D}=\left(\bar{\alpha}-\alpha_{M}\right) R+F \equiv w_{g}^{*}+\left[\left(\bar{\alpha}-\alpha_{M}\right) R-F\right], \text { in the good state. }
\end{gathered}
$$

Proposition 2 If the bank is financed with debt, all risk bears on the bank. The return to bank's lenders (households) is z in every state. Bank's income per unit of loan conditional on state realization

$$
w_{b}^{D}=F ; w_{g}^{D}=w_{g}^{*}+\left[\left(\bar{\alpha}-\alpha_{M}\right) R-F\right],
$$

and lending volume is

$$
L^{D}=\frac{K+\bar{D}(1-z)}{c^{D}}<L^{*}
$$

With debt financing, monitoring incentives require the bank being solvent in the bad state. Bank's claim-holders are perfectly insured, and all the risk bears on the bank. The bank earns an excessive rent in the good state, $w_{g}^{D}>w_{g}^{*}$, bank's pledgeable income shrinks and so does outside financing and lending, $L^{D}<L^{*}$ (by $c^{D}>c^{*}$ ). Bank's expected profits fall below the optimal level:

$$
\begin{gathered}
\pi^{D}=\left[p\left(w_{g}^{D}-F\right)+(1-p)\left(w_{b}^{D}-F\right)\right] L^{D}-K \\
=p\left(\bar{\alpha}-\alpha_{M}\right) R L^{D}-K \equiv \\
\left\{\left[p \bar{\alpha}+(1-p) \alpha_{M}\right] R-(1+F)\right\} L^{D}+\bar{D}(1-z)<\pi^{*} .
\end{gathered}
$$

If the bank could make a lower payment in the bad state and compensate its lenders in the good state, then the reward for monitoring in the bad state would increase, incentive-compatible lending and profits would expand. This gives scope for issuing claims that are appealing to sophisticated investors, the investors that can evaluate and hence bear risks. The constraint here is that these claims need to be backed by a (well defined) asset portfolio 
and be bankruptcy remote, i.e. the insolvency of the originator (the bank) does not impact on these claims. Loan portfolio securitization generates such claims. From now onwards we refer to loan-portfolio backed securities as securities. First, we ask whether there is a securitization scheme that implements the optimal allocation in "traditional banking" - deposit/debt financing coexist with loan-portfolio securitization. Second we ask whether such a securitization scheme is incentive-compatible for the bank.

\section{Securitization}

In principle, an optimal allocation attains under traditional banking.

Let the bank raise deposits $\bar{D}$, finance the optimal loan portfolio $L^{*}$, invest idle resources, $\bar{D}+K-L^{*}$, in the safe asset and then

1. forms a special purpose vehicle (SPV) and securitizes/sells the loan portfolio for a total price $P_{0}$

2. credit-enhances the deal by giving investors the option to sell their claims back to the SPV at total price $P$. To back this guarantee, the bank injects $C$ as cash collateral.

Proposition 3 The securitization arrangement $\left(P_{0}^{*}, P^{*}, C^{*}\right)$, with $P_{0}^{*}=$ $p \bar{\alpha} R L^{*}+(1-p) P^{*}, P^{*}=\left(\alpha_{M} R+F\right) L^{*}, C^{*}=P^{*}-\underline{\alpha} R L^{*}$ implements the optimal allocation.

Proof : Let us consider the bank's income for each possible realization of the portfolio solvency rate $s \in\left\{\bar{\alpha}, \alpha_{M}, \underline{\alpha}\right\}$. If $s=\bar{\alpha}$ (which occurs in the good state if the bank has monitored), then investors forgo their option and the bank collects the cash collateral. Thus its income is $P_{0}^{*}+\left(K+\bar{D}-L^{*}\right)-z \bar{D}=$ $2 F L^{*} \equiv w_{\bar{\alpha}}^{*} L^{*}$.

If $s=\alpha_{M}$ (which occurs either because the state is bad and the bank has monitored, or the state is good and the bank has not monitored), then investors exercise their options which amounts them collecting $F L^{*}$. The bank collects the cash collateral net of $F L^{*}$, and thus its income is $P_{0}^{*}-$ $F L^{*}+\left(K+\bar{D}-L^{*}\right)-z \bar{D}=F L^{*} \equiv w_{\alpha_{M}}^{*} L^{*}$.

Finally, if $s=\underline{\alpha}$ (which occurs if and only if the bank has not monitored), investors exercise their options, which amounts them collecting the entire cash collateral. The bank ends up having insufficient resources to repay 
depositors; its income is $\max \left\{P_{0}^{*}-C^{*}+\left(K+\bar{D}-L^{*}\right)-z \bar{D}, 0\right\}=0$. This proves that $\left(P_{0}^{*}, P^{*}, C^{*}\right)$ implements the optimal allocation.

Proposition 3 shows that the securitization scheme $\left(P_{0}^{*}, P^{*}, C^{*}\right)$ implements the optimal allocation. Depositors are fully insured. The risk is shared optimally between the bank and investors; the burden of debt financing (the underinvestment incentive in the bad state) is eliminated.

Protection $P^{*}$ supports the monitoring equilibrium, the cash collateral $C^{*}$ makes this investors' protection effective. A level of protection differing from $P^{*}$ undermines monitoring incentives. To be precise, it is clear from the proof of Proposition 3 that if $P<P^{*}$, then $w_{\alpha_{M}}>w_{\alpha_{M}}^{*}$, and $w_{\bar{\alpha}}<$ $w_{\bar{\alpha}}^{*}$; the bank's incentive constraint fails to hold in the good state. And if $P>P^{*}$, then $w_{\bar{\alpha}}>w_{\bar{\alpha}}^{*}$, and $w_{\alpha_{M}}<w_{\alpha_{M}}^{*}$, the bank monitors only in the good state. In the bad state, it does not monitor and fails to repay debt holders/depositors.

\subsection{Bankruptcy remoteness and seniority structure}

Will the optimal allocation be attained in "traditional banking"? The delicate issue is "bankruptcy remoteness" of securities - bank's insolvency does not impact on the securities' value. This amounts to a seniority structure where the claims that insist on the bank as a whole, i.e. bank's deposit/debt claims, have the lowest priority. The perverse effect of such a priority structure is that the bank profits by providing security holders with "excessive" protection. This dilutes monitoring incentives and results in the dilution of junior claims.

Consider the deal $\left(P_{0}^{\prime}, P^{\prime}, C^{\prime}\right)$, with $\bar{\alpha} R L^{*} \geq P^{\prime}>P^{*}, C^{\prime}=P^{\prime}-\underline{\alpha} R L^{*}$, and

$$
P_{0}^{\prime}=p \bar{\alpha} R L^{*}+(1-p) P^{\prime} .
$$

This arrangement provides investors with excessive protection, $P^{\prime}>P^{*}$, but since this is factored into the pricing, investors would break even as they do in the value-maximizing deal. However, the bank would make more profit, while depositors/debt-holders would lose. To see why, consider the state contingent parties' payoffs. In the good state, the bank's monitoring incentive constraint holds (because the condition $P^{\prime} \geq P^{*}$ holds), i.e., loan portfolio solvency rate is $\bar{\alpha}$. Since investors forgo their options, depositors' claims are backed by the securitization revenue $P_{0}^{\prime}$ and the safe asset return 
$\left(K+\bar{D}-L^{*}\right)$. Depositors are repaid, and the bank's income is $W_{g}^{\prime}$ :

$$
W_{g}^{\prime}=P_{0}^{\prime}+K+\bar{D}-L^{*}-z \bar{D} \equiv w_{\bar{\alpha}}^{*} L^{*}+(1-p)\left(P^{\prime}-P^{*}\right) .
$$

In the bad state, the bank does not monitor (by $P^{\prime}>P^{*}$ ), the portfolio solvency rate is $\underline{\alpha}$, investors exercise their options, which amounts them collecting the collateral $C^{\prime}$. The bank is insolvent:

$$
P_{0}^{\prime}-C^{\prime}+K+\bar{D}-L^{*}<z \bar{D}
$$

but this does not impact on securities' value (bankruptcy remoteness). Depositors/debtholders, de facto junior claimants, suffer losses. Their claims are worth:

$$
\begin{gathered}
\min \left\{P_{0}^{\prime}-C^{\prime}+\left(K+\bar{D}-L^{*}\right), z \bar{D}\right\}=z \bar{D}-\text { Loss } \\
\text { Loss }=\left[\left(\alpha_{M}-\underline{\alpha}\right) R-F\right] L^{*}+p\left(P^{\prime}-P^{*}\right)
\end{gathered}
$$

Depositors' losses result from the efficiency loss due to non-monitoring, i.e. $\left(\alpha_{M}-\underline{\alpha}\right) R-F$ per loan, and from the investors' protection enhancement. While the latter accrues to the bank, the loan efficiency loss is a deadweight loss.

The bank benefits. Bank's expected profit is $\pi^{\prime}$ :

$$
\begin{gathered}
\pi^{\prime}=p\left(W_{g}^{\prime}-F L^{*}\right)-K \\
\equiv \\
\pi^{*}+p(1-p)\left(P^{\prime}-P^{*}\right) .
\end{gathered}
$$

Clearly, the bank maximizes its profits by granting securities the maximum level of protection, $P^{\prime}=\bar{\alpha} R L^{*}$, which means that securities' returns are constant across states. This undoes the value-maximizing risk allocation that requires security holders to share risk. And, indeed for a level of protection that provides full insurance to security holders, the maximum lending level that satisfies bank's monitoring incentive constraint is $L^{D}$, i.e. the incentive-based lending level under the risk allocation defined by debt (see Appendix A).

Interestingly, under traditional banking, bankruptcy remoteness allows for securitization arrangements that dilute junior claims and benefit the bank, precisely when there is room for welfare-improving securitization; like 
in our model where debt is suboptimal and "properly designed" loan securitization attains efficiency. Conversely, when debt is optimal bankruptcy remoteness does not bite. Conditionally on raising debt/deposits and then securitizing the loan portfolio, the bank would still maximize profits by granting securities maximum protection but this would merely imply the same risk allocation, and hence the parties' payoffs, attained with debt, i.e. junior claims would not be diluted.

\section{Regulation: Aligning Incentives}

Under traditional banking, the incentives to the originator (bank) is to dilute debt/deposit claims by retaining all risk. Regulation could simply accept this fact and set capital requirements accordingly: Securitized loans should face the same capital requirements as the underlying loans would face if they were held on banks' balance sheets. ${ }^{5}$ Covered bonds, often named the European form of securitization, are by all means equivalent to securitization with maximum level of protection. All loans are de facto held on bank balance sheet and all face the same (risk-based) capital requirements. In our setting, capital regulation would be such to restrict lending not to exceed $L^{D}$ - the incentive-based lending level under risk retention (by Proposition 2 ). That is, capital requirement $c$ would be such that the capital constraint $c L \leq K$ is met only if $L \leq L^{D}$.

However, risk retention is suboptimal; an optimal allocation entails risk sharing between the bank and investors. The attainment of an optimal allocation requires regulatory measures apt to solve the bank's dilutionincentive problem. This boils down to induce the bank (loan originator) to internalize the cost of misallocating risk. There are two ways to attain this goal. One is "narrow-securitized banking" to be discussed below. The other is through capital requirements on loans conditioned on the extent of retained risk (albeit, via off-balance sheet commitments). ${ }^{6}$ In our setting, the capital requirement need to be conditioned on the ratio $P / L$, i.e. the protection provided to investors (security buyers) per unit of loans. Indeed,

\footnotetext{
${ }^{5}$ As suggested by Goldman Sachs (2009)

${ }^{6}$ Along these lines, US Treasury (2009).
} 
suppose the capital requirement is

$$
c_{P / L}=\left(c^{*}-\frac{\bar{D}(1-z)}{L}\right)+p\left[\frac{P}{L}-\left(\alpha_{M} R+F\right)\right]
$$

if the bank once originated $L$ loans securitizes the loan portfolio with protection $P$, then the capital constraint, $c_{P / L} L \leq K$, is met only if $P \leq$ $\left(\alpha_{M} R+F\right) L+\frac{K+\bar{D}(1-z)-c^{*} L}{p}$, or

$$
P \leq\left(\alpha_{M} R+F\right) L+\frac{c^{*}\left(L^{*}-L\right)}{p} .
$$

The bank would always monitor (see Appendix B). Its expected profit is

$$
\pi=\left[\left(p \bar{\alpha}+(1-p) \alpha_{M}\right) R-(1+F)\right] L+\bar{D}(1-z) .
$$

Profits are maximized for $L=L^{*}$, and this requires $P \leq\left(\alpha_{M} R+F\right) L^{*} \equiv$ $P^{*}$. The value-maximizing risk allocation attains.

\subsection{Narrow-Securitized Banking}

Suppose that a bank that raises deposits cannot engage in securitization, possibly as a result of a regulatory environment that favors "narrow-specialized banking". Then the bank faces the choice between i) financing asset portfolio with deposits and keep the portfolio on its balance sheet, and ii) constructing a portfolio and financing it by placing asset-backed securities. Conditionally on strategy i) the allocation and the bank's expected profit are exactly those derived for debt financing - bank's portfolio size is $L^{D}$ (Section 4). We show below that narrow-securitized banking dominates; it implements the optimal allocation, and maximizes bank profits.

Consider the bank's strategy: 1 . construct an asset portfolio $A^{*}$ that combines the loan portfolio of size $L^{*}$, and safe asset of amount $\bar{D}+K$; $A^{*}=\left\{L^{*}\right.$ loans, $\bar{D}+K$ safe asset $\} ; 2$. design two security tranches, a senior tranche and junior tranche. Senior tranche securities sell at 1 and promise to pay $z$ per unit. The junior tranche sells at total price $P_{0}$, carry a put option $P$, guaranteed by cash collateral $C$.

Define the junior tranche $\left(P_{0}^{*}, P^{*}, C^{*}\right)$, with $P_{0}^{*}=p\left[\bar{\alpha} R L^{*}+K+\bar{D}(1-z)\right]+$ $(1-p) P^{*}, P^{*}=\left(\alpha_{M} R+F\right) L^{*}+K+\bar{D}(1-z)$, and $C^{*}=2 F L^{*}$. 
Proposition 4 Portfolio $A^{*}$ backing a senior tranche that sells at 1 and promises z per unit, and a junior tranche $\left(P_{0}^{*}, P^{*}, C^{*}\right)$ implements the optimal allocation, and is the arrangement that maximizes bank's profits.

Proof : First notice that $P_{0}^{*}=L^{*}+C^{*}$, i.e. the loan portfolio can be financed and the cash collateral $C^{*}$ can be injected. Next consider the bank's income for each possible realization of the portfolio solvency rate $s \in\left\{\bar{\alpha}, \alpha_{M}, \underline{\alpha}\right\}$. If $s=\bar{\alpha}$, then investors forgo their option and the bank collects the cash collateral. Thus its income is $P_{0}^{*}-L^{*} \equiv 2 F L^{*} \equiv w_{\bar{\alpha}}^{*} L^{*}$. If $s=\alpha_{M}$, then investors exercise their options, which amounts them collecting $F L^{*}$. The bank collects the cash collateral net of $F L^{*}$, and thus its income is $P_{0}^{*}-L^{*}+F L^{*} \equiv F L^{*} \equiv w_{\alpha_{M}}^{*} L^{*}$.

Finally, if $s=\underline{\alpha}$, investors exercise their options, which amounts them collecting the entire cash collateral. The bank loses the cash collateral and ends up with income $P_{0}^{*}-L^{*}-C^{*}=0$. This proves that $\left(P_{0}^{*}, P^{*}, C^{*}\right)$ implements the optimal allocation and maximizes bank's profits

Narrow-securitized banking implements the optimal allocation. ${ }^{7}$ The key is that all securities insist on the same portfolio and their seniority is defined ex ante (tranching), which implies that bankruptcy remoteness does not bite. This solution could be attained via outright restrictions on bank activity, but it could also result endogenously in response to a capital regulation of commercial banks such that securitized loans face the same capital requirements as the underlying loans would face if held on bank's balance sheet. Such regulation prevents capital arbitrage between unsecuritized and securitized loans in traditional banking (it limits bank asset size to $L^{D}$ ), and thus gives scope for targeting greater profits via narrow-securitized banking.

\section{Concluding Remarks}

Popular accounts of the financial crisis place much blame on the weakened monitoring incentives of the originate-to-distribute model, the 2009 Dodd-Frank Law and the ongoing regulatory reform, notably the Basel III agreement, amendments to the Capital Requirements Directive (CRD) and

\footnotetext{
${ }^{7}$ This parallels the proposal of narrow banks for securitization of Gorton and Metrick (2010).
} 
Solvency II, contain a provision intended to reduce moral hazard by requiring a minimum level of risk retention by originators. Our analysis suggests that the problem to be addressed is rather the incentive to retain excessive risk. Bankruptcy remoteness - the insolvency of the sponsor (the bank that has originated the loans) has no impact on the securities - and the fact that the protection provided to security holders is factored into the pricing makes it profitable to grant excessive credit enhancement (excessive risk retention). This dilutes the bank's monitoring incentives and by so doing it dilutes debt/deposit claims, the claims that under bankruptcy remoteness have the lowest priority. Measures aimed at aligning incentives succeed to the extent that make the bank (loan originator) to internalize the cost of misallocating risk. We have explored two avenues for attaining this goal. One is capital regulation, capital requirements on loans conditioned on the extent of retained risk (albeit, via off-balance sheet commitments). The other is "narrow-securitized banking", attainable with outright restrictions on bank activity, and/or by a capital regulation of traditional banks that imposes the same capital requirement on loans, irrespective of whether loans are securitized or held on bank's balance sheet. We have shown that under narrow-securitized banking the optimal allocation attains. Bank profits (and welfare) are maximized by constructing a (well defined) portfolio and placing securities backed by the portfolio. Securities are ranked by seniority, and the safe claims that depositors (and more generally, some classes of investors) target are made such by granting them absolute priority. 


\section{APPENDIX A}

Consider a lending portfolio of size $L$, and a securitization arrangement that gives security holders maximum protection: $\left(P_{0}, P, C\right), P_{0}=p \bar{\alpha} R L+$ $(1-p) P, P=\bar{\alpha} R L, C=P-\underline{\alpha} R L$. Bank's income contingent on solvency rate $s \in\left\{\bar{\alpha}, \alpha_{M}, \underline{\alpha}\right\}$ is:

$$
\begin{aligned}
& W_{\bar{\alpha}}=P_{0}+(K+\bar{D}-L)-z \bar{D} \equiv \bar{\alpha} R L+K+\bar{D}(1-z)-L ; \\
& W_{\alpha_{M}}=\max \left\{P_{0}-C+\alpha_{M} R L-\underline{\alpha} R L+K+\bar{D}(1-z)-L, 0\right\} \\
& \quad \equiv \max \left\{\alpha_{M} R L+K+\bar{D}(1-z)-L, 0\right\} \\
& \begin{array}{l}
W_{\underline{\alpha}}=\max \left\{P_{0}-C+K+\bar{D}(1-z)-L, 0\right\} \\
\equiv \max \{\underline{\alpha} R L+K+\bar{D}(1-z)-L, 0\} .
\end{array}
\end{aligned}
$$

The monitoring incentives constraints, $W_{\bar{\alpha}}-F \geq W_{\alpha_{M}}, W_{\alpha_{M}} \geq W_{\underline{\alpha}}$,

hold if and only if $L \leq L^{D} \equiv \frac{K+\bar{D}(1-z)}{1+F-\alpha_{M} R}$ (by the same reasoning at Proposition 2).

\section{APPENDIX B}

It is sufficient to prove that the bank finds it optimal to monitor in the bad state. Let $W_{\alpha_{M}}, W_{\underline{\alpha}}$ denote the bank's income conditional on the portfolio solvency rate $\alpha_{M}, \underline{\alpha}$, respectively. The bank's monitoring incentive constraint in the bad state is:

$$
W_{\alpha_{M}}-F L \geq W_{\underline{\alpha}}
$$

For $\left(P_{0}, P, C\right)$, with $P_{0}=p \bar{\alpha} R L+(1-p) P, C=P-\underline{\alpha} R L$, and $\bar{\alpha} R L \geq P \geq$ $P^{*} \equiv\left(\alpha_{M} R+F\right) L$,

$$
\begin{gathered}
W_{\alpha_{M}}=\max \left[P_{0}-C+\left(\alpha_{M}-\underline{\alpha}\right) R L+\bar{D}(1-z)-(K-L), 0\right] \\
W_{\underline{\alpha}}=\max \left[P_{0}-C+\bar{D}(1-z)-(K-L), 0\right]
\end{gathered}
$$

and the necessary and sufficient condition for monitoring is

$$
\left\{c^{*}+p\left[\frac{P}{L}-\left(\alpha_{M} R+F\right)\right]\right\} L \leq K+\bar{D}(1-z)
$$

which reduces to $P \leq\left(\alpha_{M} R+F\right) L+\frac{K+\bar{D}(1-z)-c^{*} L}{p}$, or equivalently condition (8). 


\section{References}

Acharya, A., Schnabl, P., Suarez, G. (2013) Securitization without risk transfer, Journal of Financial Economics 107, 515-536.

Allen, F., Carletti, E. (2006) Credit risk transfer and contagion, Journal of Monetary Economics 53, 89-111.

Ayotte, K., Gaon, S.(2011) Asset-backed securities: Costs and benefits of "bankruptcy remoteness", Review of Financial Studies 24, 1299-1335.

Benveniste, L.M., Berger, A.N. (1987) Securitization with recourse: An instrument that offers uninsured bank depositors sequential claims, Journal of Banking and Finance 11, 403-424.

Bhattacharya, S., Chiesa, G. (1995) Proprietary information, financial intermediation and research incentives, Journal of Financial Intermediation 4, 328-357.

Bhattacharya, S., Thakor, A. (1993) Contemporary banking theory, Journal of Financial Intermediation 3, 2-50.

Campbell, T.S., Kracaw, W.A. (1980) Information production, market signalling and the theory of financial intermediation, Journal of Finance 35, 863-882.

Carlstrom, C. T., Samolyk, K.A. (1995) Loan sales as a response to market-based capital constraints, Journal of Banking and Finance 19, 627646.

Cebenoyan, S., Strahan, P.E., 2004. Risk management, capital structure and lending at banks. J. Banking Finance 28, 19-43.

Cerasi, V., Rochet, J.J. (2013) Rethinking the regulatory treatment of securitization, Journal of Financial Stability forthcoming.

Chiesa, G. (1992) Debt and warrants: Agency problems and mechanism design, Journal of Financial Intermediation 2, 237-254.

Chiesa, G. (2008) Optimal credit risk transfer, monitored finance, and banks, Journal of Financial Intermediation 17, 464-477.

Dang, T.V., Holmstrom, B., Gorton, G. (2012) Ignorance, Debt and Financial Crises, working paper.

Datta, S., Iskandar-Datta, M., Patel, A. (1999) Bank monitoring and the pricing of corporate debt, Journal of Financial Economics 51, 435-449.

DeMarzo, P. (2005) The pooling and tranching of securities: A model of informed intermediation. Review of Financial Studies 18, 1-35. 
Diamond, D. (1984) Financial intermediation and delegated monitoring, Review of Economic Studies 51, 393-414.

Duffee, G.R., Zhou, C. (2001) Credit derivatives in banking: Useful tools for managing risk?, Journal of Monetary Economics 48, 25-54.

Fama, E.F. (1985) What's different about banks?, Journal of Monetary Economics 15, 29-39.

Fender, I., Mitchell, J. (2009) The future of securitisation: how to align incentives?, BIS Quarterly Review, September 2009, 27-43.

Goldman Sachs (2009) Effective regulation: Part 3 - Helping restore transparency, Global Markets Institute, June.

Gorton, G., Metrick, A. (2010) Regulating the shadow banking system, Brookings Papers on Economic Activity, Fall, 261-297.

Gorton, G., Metrick, A. (2012) Securitization, in: G. Constantinides, M. Harris, and R. Stulz (Eds.), The Handbook of the Economics of Finance, forthcoming.

Gorton, G.B., Pennacchi, G.G. (1995) Banks and loan sales marketing nonmarkeatable assets, Journal of Monetary Economics 35, 389-411.

Greenlaw, D., Hatzius, J., Kashyap, A., Shin, H.S. (2008) Leveraged losses: Lessons from the mortgage market meltdown, US Monetary Policy Forum Report No. 2.

Hellwig, M.,1991. Banking, financial intermediation and corporate finance. In: Giovannini A., Mayer, C. (Eds.), European Financial Integration. Cambridge Univ.Press, Cambridge, pp. 35-63.

Holmstrom, B., Tirole, J. (1997) Financial intermediation, loanable funds and the real sector, Quarterly Journal of Economics 112, 663-91.

Innes, R.D. (1990) Limited liability and incentive contracting with exante action choices, Journal of Economic Theory 52, 45-67.

James, C. (1987) Some Evidence on the Uniqueness of Bank Loans, Journal of Financial Economics 19, 217-235.

Lummer, S.L., McConnell, J.C. (1989) Further evidence on the bank lending process and the capital market response to bank loan agreements, Journal of Financial Economics 25, 99-122.

Morrison, A.D. (2005) Credit derivatives, disintermediation and investment decisions, Journal of Business 78, 621-647.

Parlour, C., Plantin, G. (2008) Loan sales and relationship banking, Journal of Finance 63, 1291-1314. 
Parlour, C., Winton, A. (2013) Laying off credit risk: Loan Sales versus credit default swaps, Journal of Financial Economics 107, 25-45.

Pennacchi, G. G. (1988) Loan sales and the cost of bank capital, Journal of Finance 43, 375-395.

Shin, H.S. (2010) Risk and Liquidity, Oxford University Press, Oxford.

US Treasury (2009) Financial regulatory reform: A new foundation. June. 


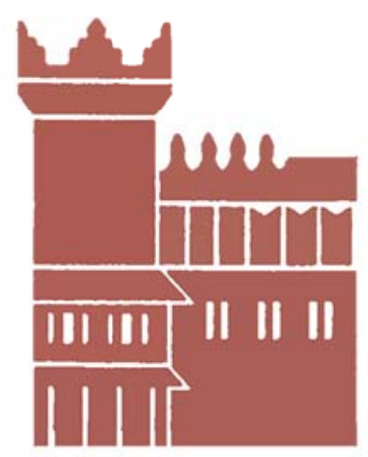

Alma Mater Studiorum - Università di Bologna DEPARTMENT OF ECONOMICS

Strada Maggiore 45

40125 Bologna - Italy

Tel. +39051 2092604

Fax +390512092664

http://www.dse.unibo.it 